\title{
Physicochemical Properties and Oxidative Stability of Milk Fortified with Spray-Dried Whey Protein Concentrate-Iron Complex and In Vitro Bioaccessibility of the Added Iron
}

\author{
Indrajeet Singh Banjare', \\ Kamal Gandhi**, Khushbu \\ Sao', Sumit Arora' and \\ Vanita Pandey ${ }^{2}$ \\ 'Dairy Chemistry Division, National \\ Dairy Research Institute, P.O. Box \\ 132001, Karnal, India \\ ${ }^{2}$ Quality and Basic Sciences, Indian \\ Institute of Wheat and Barley \\ Research, P.O. Box 132001, Karnal, \\ India
}

Received: 17 July 2018

Accepted: 24 January 2019

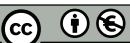

${ }^{*}$ Corresponding author:

Phone: +919729134444

Fax: 0184225004

E-mail: kamalgandhindri@gmail.com

ORCID IDs: 0000-0002-1285-0139

(Banjare), 0000-0002-2542-2299 (Gandhi), 0000-0002-7209-2456 (Sao) 0000-0003-2261-2385 (Arora), 0000-0002-1286-1110 (Pandey)

\begin{abstract}
SUMMARY
In the present study, spray-dried whey protein concentrate-iron (WPC-Fe) complex was prepared using a laboratory-scale spray drier under the optimized conditions of inlet temperature $180^{\circ} \mathrm{C}$, flow rate $2.66 \mathrm{~mL} / \mathrm{min}$ and total solids $15 \%$ with the objective to make iron compatible with food products. In order to remove the free iron from the bound iron, standardised method involving centrifugation and ultrafiltration was employed. Further, the retentate was subjected to spray drying to produce WPC-Fe complex. Milk fortified with WPC-Fe complex ( $\gamma$ (iron) $=15 \mathrm{mg} / \mathrm{L}$ ) showed non-significant difference in heat stability, rennet coagulation time, colour estimation, curd tension, viscosity and sensory attributes as compared to control milk. In vitro bioaccessibility of iron and induction period of the fat from milk fortified with WPC-Fe complex were found to be slightly higher $(p<0.05)$ than that of milk fortified with iron alone. Therefore, milk can be fortified with up to $15 \mathrm{mg} / \mathrm{L}$ iron in the form of WPCFe complex without significantly affecting its physicochemical properties.
\end{abstract}

Key words: whey protein, iron, spray drying, milk, bioaccessibility, oxidative stability

\section{INTRODUCTION}

Iron deficiency is usually the result of inadequate dietary intake of iron, poor utilization of iron from ingested food, or a combination of the two. Iron deficiency anaemia often results in chronic heart failure, kidney disease, cancer and inflammatory bowel disease (1). Currently, there is a number of iron sources available as food fortificants. Based on bioavailability, they are classified into two groups: the highly bioavailable iron sources (e.g. ferrous sulfate and ferrous fumarate), which may cause organoleptic changes such as poor product acceptability and shortened shelf life, and those with poor bioavailability (e.g. iron(III) diphosphate and reduced iron), which are more compatible with the foods (2). The challenge for the food scientists and the food industry is to develop a fortification technology that will make either the bioavailable iron sources compatible with the food vehicle or the compatible ones more bioavailable.

Different forms of micronutrients ranging from mineral salts to mineral chelates are available that have been approved as suitable mineral sources for food fortification (3). The effectiveness of these fortificants is strongly influenced by iron absorption enhancers and inhibitors in the diet. Direct addition of iron to milk or dairy products induces several physicochemical changes like chemical reactivity with the milk components, lack of stability under food processing and storage conditions and decreased bioavailability of the fortificants (4). In order to increase the lipid oxidative stability and to control metal reactivity, the food industry uses divalent ion chelators such as Na-EDTA, citric, malic and phytic acids or antioxidants which adversely affect the functionality of other food components (5). There is an increasing global demand for cheap and effective iron fortificants to combat iron deficiency. The success of iron fortification is dependent on delivering a significant level of bioavailable iron without affecting the taste and appearance of the final product.

Cheese whey, a byproduct of cheese-producing industries, is considered as an environmental pollutant due to its high biochemical and chemical oxygen demand. The high 
organic load of whey arises from the presence of residual milk components. Increased production of whey as a result of an increase in the demand for dairy products poses a severe management problem. In order to overcome this problem, various technological methods have been employed to convert whey into value-added products (6). Milk proteins can act as natural antioxidants by binding minerals and thus inhibiting the oxidation reactions (7). Whey protein concentrate (WPC), because of its structural and functional properties and easy availability in the industry, was used in this study for complex formation with iron. Limited attempts have been made for the determination of iron-binding ability of WPC and the feasibility of such complex as a food fortificant. WPC-iron (WPC-Fe) complex prepared using lyophilisation showed better solubility, yield and also fairly high capacity of mineral retention than complexes formed using milk protein concentrate and sodium caseinate (8). However, lyophilisation is time-consuming and costly process (9) and hence not feasible for commercial application. Moreover, it also requires an additional milling step to produce particles of definite size. Spray drying is a fast, continuous, cost-effective, reproducible, scalable and well-established technique for the production of dry powders from a solution by atomization into hot drying air $(10,11)$. It has always remained an active field of innovation in pharmaceutical, food and flavour industry $(10,12)$.

Milk is a relatively poor source of iron $(0.2-0.5 \mathrm{mg} / \mathrm{L})$ so milk and milk products are generally selected for micronutrient fortification as they are processed through centralized control systems, regularly consumed by all age and social groups, and also because the stability and bioavailability of the nutrients remain high (6). The aim of the present work is to provide a form of organic fortificant that can provide one-third of the recommended daily allowance ( 8 and $18 \mathrm{mg} /$ day for men and women, respectively) (13) of iron per serving of milk with minimum changes in its sensory and physicochemical aspects. Therefore, in the present study, spray-dried WPC-Fe complex is added to milk to overcome the limitations associated with other inorganic iron fortificants.

\section{MATERIALS AND METHODS}

\section{Materials}

Whey protein concentrate (WPC) containing $80 \%$ protein (WPC 80) was procured from Davisco Foods International Co. (Le Suer, MN, USA) and $\mathrm{FeSO}_{4} \cdot 7 \mathrm{H}_{2} \mathrm{O}$ from Sigma Aldrich, Merck (St. Louis, MO, USA).

\section{Preparation of WPC-Fe complex}

WPC-Fe complex was prepared by following the method of Shilpashree (8) with some modifications, viz. production of powder by spray drying instead of lyophillization. WPC $1.0 \%$ solution was prepared in deionised water and iron solution was added gradually to obtain a final iron concentration of $3 \mathrm{mM}$ with constant stirring at $600 \mathrm{rpm}$ using magnetic stirrer (SPINOT MC 02; Tarsons Products Pvt. Ltd., Kolkata, India). The $\mathrm{pH}$ of the solution was adjusted to 6.6 and was left undisturbed at $20^{\circ} \mathrm{C}$ for $2 \mathrm{~h}$. The mixture was then centrifuged (high-speed refrigerated centrifuge model 6500; KUBOTA Corporation, Tokyo, Japan) at $12000 \times g$ and $20^{\circ} \mathrm{C}$ for $30 \mathrm{~min}$. Supernatant containing soluble iron and protein was carefully decanted and filtered through Whatman no. 1. Further, the filtered supernatant was passed through a Hydrosart ${ }^{\circledR}$ ultrafiltration cassette ( $M=10$ kDa; Sartorius India Pvt. Ltd., Mumbai, India) to separate the soluble bound iron (retentate) from the soluble free iron (permeate). The retentate was concentrated to $15 \%$ total solids and subsequently spray dried.

\section{Production of WPC-Fe complex}

A tabletop spray dryer (SPD-P-111; Technosearch Instruments, Mumbai, India) equipped with co-current nozzle was used for the manufacture of spray-dried WPC-Fe complex. Processing conditions used were: inlet temperature $180^{\circ} \mathrm{C}$, $15 \%$ total solids in the WPC-Fe complex solution and flow rate $2.66 \mathrm{~mL} / \mathrm{min}$. Central composite rotatable design (CCRD) of response surface methodology using Design-Expert v. 10.0.8 (14) optimized these conditions at which maximum yield, solubility and minimum moisture content were obtained.

\section{Fortification of WPC-Fe complex in toned milk}

\section{Collection of milk samples}

Fresh cow and buffalo milk were collected from the herd of cows and buffaloes maintained in the cattle yard of National Dairy Research Institute, Karnal, Haryana, India, and mixed in equal proportions (1:1). The mixed milk was then standardised to obtain toned milk (3\% fat and $8.5 \%$ solids-not-fat (SNF)).

\section{Addition of iron to milk}

Four different concentrations of iron (in the form of WPC-Fe complex and $\mathrm{FeSO}_{4}$ ) were selected, viz. 10, 15, 20 and $25 \mathrm{mg} / \mathrm{L}$, and the most suitable concentration was optimized for the fortification of toned milk on the basis of sensory evaluation.

\section{Technology of fortification}

Toned milk was taken in clean and dried conical flasks and the fortificant (both WPC-Fe complex and $\mathrm{FeSO}_{4}$ ) was added to obtain concentrations of 10, 15, 20 and $25 \mathrm{mg} / \mathrm{L}$ of iron in the milk. Fortificants were then mixed for $10 \mathrm{~min}$ with the help of magnetic stirrer (SPINOT MC 02; Tarsons Products Pvt. Ltd.) at $600 \mathrm{rpm}$ for the complete dissolution. After the addition of fortificant, the milk was heated at $63^{\circ} \mathrm{C}$ for $30 \mathrm{~min}$ followed by cooling to $4^{\circ} \mathrm{C}$ in an ice bath.

\section{Sensory evaluation}

Sensory analysis of both fresh and stored milk samples was conducted after keeping the pasteurised samples under refrigerated conditions $\left(4-7^{\circ} \mathrm{C}\right)$ for $2 \mathrm{~h}$. Optimization of iron 
level (both WPC-Fe complex and $\mathrm{FeSO}_{4}$ ) for milk fortification was done on the basis of sensory acceptability. Sensory evaluation was carried out by a panel of fifteen trained judges (10 males and 5 females, 21-30 years of age) who were asked to grade any change in colour and appearance, odour, taste and mouthfeel of the fortified milk as compared to control sample. Standard composite score card for sensory analysis of pasteurised milk given by Bureau of Indian Standards (BIS) (15) with slight modifications was used. In flavour characteristics, the main focus was on metallic, rancid and oxidized flavour. All sensory assessments took place at Dairy Chemistry Department of National Dairy Research Institute, Karnal, Haryana, India. The sensory booth environment was held at a constant temperature $\left(20^{\circ} \mathrm{C}\right)$, red lighting was used to obscure any colour differences between the samples and a positive airflow removed any odours from the testing area. Saline water $(0.89 \% \mathrm{NaCl}$ solution at room temperature) was provided as palate cleanser for rinsing the mouth and cleaning the tongue before testing each sample.

\section{Heat stability}

After the adjustment of $\mathrm{pH}$, the heat stability of control milk and that of the milk fortified with iron as WPC-Fe complex and iron salt was determined as heat coagulation time according to the method of Jairam et al. (16). Each milk sample was divided into eight lots of $50 \mathrm{~mL}$ and adjusted to $(20 \pm 0.1)$ ${ }^{\circ} \mathrm{C}$ in a water bath (SUB Aqua 18 Plus; Grant Instruments, Cambridge, UK). The first lot was kept as control and the $\mathrm{pH}$ of other lots was adjusted between 6.4 and 7.0 at $0.1 \mathrm{pH}$ unit interval with the addition of acid or base when necessary. After the adjustment of $\mathrm{pH}$, all the lots of milk were kept at refrigerated temperature $\left(4-7^{\circ} \mathrm{C}\right)$ for $30 \mathrm{~min}$ and temperature was then brought to $(20 \pm 0.1)^{\circ} \mathrm{C}$ in a water bath. The $\mathrm{pH}$ of the lots was readjusted with the addition of either acid or base when necessary. Food grade stabilisers, viz. $\mathrm{NaH}_{2} \mathrm{PO}_{4}$ and $\mathrm{Na}_{2} \mathrm{HPO}_{4}$ (Sigma Aldrich, Merck, St. Louis, MO, USA) were used for adjustment of milk pH.

For the determination of heat stability of individual milk samples, $2 \mathrm{~mL}$ of milk from each lot were taken in Corning glass tube (10 cm long, $8 \mathrm{~mm}$ internal diameter) in duplicates and corked at both ends with silicone rubber corks. The tubes were then rocked at the rate of 8 cycles per minute in a metal carriage inside the hot $\left((140 \pm 1.0){ }^{\circ} \mathrm{C}\right)$ paraffin oil in a thermostatically controlled oil bath (Akash Deep Scientific Industries, New Delhi, India). The heat coagulation time in minutes was recorded as the time elapsed between the moment the tubes were dipped into the oil and the appearance of first visible clot. To facilitate the observation of clotting, a lamp was used which illuminated the samples from above. The heat coagulation time was recorded using a stopwatch. The graphs were then drawn between heat coagulation times (min) on the $y$-axis and $\mathrm{pH}$ on the $\mathrm{x}$-axis. Heat stability was determined from the maxima of the heat coagulation time/pH graph thus obtained.

\section{Colour estimation}

Hunter Lab ColorFlex Colorimeter (Hunter Associates Laboratory Inc., Reston, VA, USA) was used to measure the change of the colour of milk with the addition of iron in the form of WPC-Fe complex as compared to that with added $\mathrm{FeSO}_{4}$. Milk samples were heated $\left(63^{\circ} \mathrm{C} / 30 \mathrm{~min}\right)$ and stored under refrigerated conditions $\left(4-7^{\circ} \mathrm{C}\right)$ for $24 \mathrm{~h}$. Then they were brought to room temperature and colour measurements were done in terms of $L^{*}$ [dark (0-50) and light (50-100)], $a^{*}$ [green (negative numbers) and red (positive numbers)] and $b^{*}$ [blue (negative numbers) and yellow (positive numbers)].

\section{Rennet coagulation time}

Rennet coagulation time of control and milk fortified with WPC-Fe complex and iron salt was determined according to the method described by Berridge (17). A volume of $10 \mathrm{~mL}$ milk was transferred to a test tube and $1 \mathrm{~mL}$ of $0.2 \%$ rennet solution was added to it. The contents were mixed by tilting the test tube at an angle of $45^{\circ}$ and the appearance of the first clot was monitored at regular intervals. The time taken from the point of addition of rennet solution to milk to the observation of the first clot was noted as rennet coagulation time. The experiment was conducted using thermostatically controlled water bath (SUB Aqua 18 Plus; Grant Instruments) at $(30 \pm 1)^{\circ} \mathrm{C}$.

\section{Curd tension}

Curd tension of control and milk fortified with WPC-Fe complex and iron salt was determined as per the method described by Chandrasekhara et al. (18). A simple type of curd tension meter was employed. It consisted of three sharp stainless steel knives of the size $2.54 \mathrm{~cm} \times 0.64 \mathrm{~cm}$, welded in the form of ' $\mathrm{H}$ '. A thin vertical rod was bent in the form of a hook which was attached to the thread carrying the pan over a frictionless pulley. The curd tension of milk samples was determined in uniform size beakers of $100 \mathrm{~mL}$ capacity. A volume of $50 \mathrm{~mL}$ milk was taken in a beaker and heated at $(30 \pm 1)^{\circ} \mathrm{C}$. The curd tension knife was then placed in the beaker and 0.5 $\mathrm{mL}$ of $0.015 \%(\mathrm{~m} / \mathrm{V})$ Meito microbial rennet (Meito Sangyo Co., Ltd., Tokyo, Japan) was added. Milk was stirred immediately and placed in a BOD Incubator (Narang Scientific Works Pvt. Ltd, New Delhi, India) maintained at $(30 \pm 1){ }^{\circ} \mathrm{C}$. The pan was loaded with weights until the curd tension knife was able to cut its way through the curd. The mass expressed in grams was taken as a measure of curd tension.

\section{In vitro bioaccessibility of iron from milk fortified with WPC-Fe complex}

Bioaccessibility of control and milk fortified with WPC-Fe complex and iron salt was evaluated by dialysis method of Sachdeva et al. (19). Approximately $5 \mathrm{~mL}$ sample solution (WPC-Fe and $\mathrm{FeSO}_{4}$ adjusted to $500 \mu \mathrm{M}$ iron concentration) were transferred to a flask and prepared saliva solution $(1.92 \mathrm{~mL}$, $\mathrm{pH}=6.5$; Sigma Aldrich, Merck) was added, after which the 
samples were incubated in a shaking water bath (SUB Aqua 18 Plus; Grant Instruments) at $37^{\circ} \mathrm{C}$ and $95 \mathrm{rpm}$ for $5 \mathrm{~min}$. After incubation, gastric juice ( $2.89 \mathrm{~mL}$; Sigma Aldrich, Merck) was added, $\mathrm{pH}$ was adjusted to 1.1 with $\mathrm{HCl}$ (Sigma Aldrich, Merck) and the solution was incubated at $37{ }^{\circ} \mathrm{C}$ for $2 \mathrm{~h}$. Freshly prepared duodenal juice ( $5.35 \mathrm{~mL}$; Sigma Aldrich, Merck) and bile solution (1.92 mL; Sigma Aldrich, Merck) on the day of the assay were added to the solution after neutralisation of the $\mathrm{pH}$ (7.8). Final volume was approx. $15 \mathrm{~mL}$, which was then incubated at $37^{\circ} \mathrm{C}$ for $3 \mathrm{~h}$. Next, the solution was transferred to an Amicon UF centrifuge tube (Sigma Aldrich, Merck) (molecular mass cut-off $10 \mathrm{kDa}$ ) and centrifuged in a high-speed refrigerated centrifuge (KUBOTA model 6500; KUBOTA Corporation) at 5000 rpm for $30 \mathrm{~min}$. Iron content in the permeate was then determined by atomic absorption spectrophotometer (AAS) (Shimadzu, Tokyo, Japan) to estimate the digestibility of the added iron under simulated gastrointestinal conditions. Bioaccessibility of iron was calculated from the concentration of the iron that had passed the ultrafiltration membrane proportional to the total iron concentration in the sample:

$$
\text { Bioaccessibility }=\left(\frac{\gamma(\mathrm{Fe})_{\text {dialysate }}}{\gamma(\mathrm{Fe})_{\text {sample }}}\right) \cdot 100
$$

where $\gamma(\mathrm{Fe})$ is the concentration of iron in $\mathrm{mg} / \mathrm{L}$.

\section{Storage studies}

Milk samples fortified with iron (WPC-Fe complex and iron salt $(\gamma($ iron $)=15 \mathrm{mg} / \mathrm{L}))$ along with control samples were stored at refrigerated temperature $\left(4-7^{\circ} \mathrm{C}\right)$ for 7 days. Then, each milk sample was evaluated for sensory acceptability, viscosity and oxidative stability.

\section{Absolute viscosity}

The kinematic viscosity of control and milk fortified with WPC-Fe complex and iron salt samples at $27^{\circ} \mathrm{C}$ was measured with an Ostwald viscometer (LABCO ${ }^{\circledR}$ Laboratory Glassware $\mathrm{Co}$, Ambala, India). The density of samples at $27^{\circ} \mathrm{C}$ was analysed using pycnometer (LABCO Laboratory Glassware Co). Temperature was maintained at exactly $27^{\circ} \mathrm{C}$ in thermostatically controlled transparent glass water bath (SUB Aqua 18 Plus, Grant Instruments). The absolute viscosity (in $\mathrm{mPa} \cdot \mathrm{s}$ ) was calculated according to the equation (20):

$$
\mu=v \cdot \rho
$$

where $\mu$ is the absolute (dynamic) viscosity, $v$ is kinematic viscosity $\left(\mathrm{cm}^{2} / \mathrm{s}\right)$ and $\rho$ is density $\left(\mathrm{g} / \mathrm{cm}^{3}\right)$.

\section{Oxidative stability}

Control and fortified milk samples were pasteurised and stored in polyethylene pouches and glass bottles under refrigerated conditions $\left(4-7^{\circ} \mathrm{C}\right)$ for 7 days. To check the effect of WPC-Fe complex fortification on the oxidative stability of milk, cream was separated from each sample at the beginning, and on the $3 \mathrm{rd}, 5$ th and 7 th day of storage, clarified into ghee at $120^{\circ} \mathrm{C}(20)$ and filtered. These ghee samples were used to determine the oxidative stability using the following parameters: thiobarbituric acid (TBA) test (21), induction time (22), peroxide value and free fatty acid content (23).

TBA value of the fat extracted from the milk fortified with WPC-Fe complex

TBA value of the fat extracted from milk fortified with WPC-Fe complex was evaluated by the method described by Sidwell et al. (21). The secondary oxidation products were analysed using spectrophotometer (UV-2700; Shimadzu Corporation, Kyoto, Japan). A mass of $3.0 \mathrm{~g}$ of molten fat was weighed accurately in a glass stoppered test tube. To this, $10.0 \mathrm{~mL} \mathrm{CCl}_{4}$ and $10.0 \mathrm{~mL}$ TBA reagent (both from Sigma Aldrich, Merck) were added. The content was shaken (Spinix vortex shaker 3020; Tarsons Products Pvt. Ltd) vigorously at about $125 \mathrm{rpm}$ for $4 \mathrm{~min}$. Test tubes were left undisturbed to obtain two clear separated layers. A volume of $5.0 \mathrm{~mL}$ of aqueous layer was transferred to a test tube, and incubated in boiling water bath (SUB Aqua 18 Plus; Grant Instruments) for $30 \mathrm{~min}$. The red coloured supernatant was decanted and its absorbance was measured spectrophotometrically (UV-2700; Shimadzu Corporation) at $532 \mathrm{~nm}$ in a $1-\mathrm{cm}$ light path. All measurements were run in triplicates.

Estimation of induction time of fat extracted from milk fortified with WPC-Fe complex

The induction time of the fat extract was estimated using Rancimat (Metrohm Rancimat Model 743; Herisau, Switzerland) according to the method of Pawar et al. (22). The oxidative stability was expressed as induction time (h). A stream of air was bubbled into completely melted fat extract $(3 \mathrm{~g})$ in a reaction vessel placed in an electric heating block. Effluent air containing volatile organic acids from the sample was collected in a measuring vessel containing double distilled water $(60 \mathrm{~mL})$. The conductivity of the water was measured automatically during the oxidation process. Induction time of anhydrous milk fat made from control and milk fortified with WPC-Fe complex and an iron salt sample was measured. A mass of $3.0 \mathrm{~g}$ of anhydrous milk fat from different samples was weighed accurately. Temperature of heating blocks was set at 120 and $130^{\circ} \mathrm{C}$ and a constant air flow rate $(20 \mathrm{~L} / \mathrm{h})$ was maintained throughout the run.

Peroxide value of fat extracted from milk fortified with WPC-Fe complex

A mass of $1 \mathrm{~g}$ of molten fat was weighed accurately into a 250-mL stoppered Erlenmeyer flask. Then, $20 \mathrm{~mL}$ of mixed solvent (glacial acetic acid/chloroform, 2:1, V/V; (Sigma Aldrich, Merck) were added and the flask was then swirled until the fat dissolved, followed by the addition of $0.5 \mathrm{~mL}$ of saturated $\mathrm{KI}$ (Sigma Aldrich, Merck, St. Louis), then finally kept undisturbed for $1 \mathrm{~min}$. The mixture was heated in a boiling water bath (SUB Aqua 18 Plus; Grant Instruments) up to boiling and the tip of 
the flask was closed with a finger after vapours started to form and boiling was continued for $30 \mathrm{~s}$. Generated vapours were condensed under stream of running tap water. A volume of $25 \mathrm{~mL}$ of distilled water was added, followed by $0.5 \mathrm{~mL}$ of $1 \%$ starch indicator ( $\mathrm{Kl}$; Sigma Aldrich, Merck). At this point dark blue/brown colour appeared. The mixture was then titrated against $0.001 \mathrm{M} \mathrm{Na}_{2} \mathrm{~S}_{2} \mathrm{O}_{3}$ (Sigma Aldrich, Merck) until disappearance of colour. Blank without sample was also run simultaneously. The peroxide value (PV) in $\mathrm{mmol}$ of peroxide per $\mathrm{kg}$ of fat was calculated as:

$$
\mathrm{PV}=\frac{\left(V_{s}-V_{\mathrm{b}}\right) \cdot c\left(\mathrm{Na}_{2} \mathrm{~S}_{2} \mathrm{O}_{3}\right) \cdot 1000 \cdot 8}{m}
$$

where $V_{\mathrm{s}}(\mathrm{mL})$ is the volume of $\mathrm{Na}_{2} \mathrm{~S}_{2} \mathrm{O}_{3}$ required for titration of sample, $V_{b}(\mathrm{~mL})$ is the volume of $\mathrm{Na}_{2} \mathrm{~S}_{2} \mathrm{O}_{3}$ required for titration of blank, $c\left(\mathrm{Na}_{2} \mathrm{~S}_{2} \mathrm{O}_{3}\right)$ is the concentration $(\mathrm{mol} / \mathrm{L})$, and $m$ is the mass of sample $(\mathrm{g})$.

Free fatty acid content of fat extracted from milk fortified with WPC-Fe complex

A mass of $5.0 \mathrm{~g}$ of ghee was accurately weighed in a $250-\mathrm{mL}$ conical flask. In a second flask, $50 \mathrm{~mL}$ of ethanol (Sigma Aldrich, Merck) were heated to boiling point and while still above $70^{\circ} \mathrm{C}$, it was neutralised with $0.1 \mathrm{M} \mathrm{NaOH}$ (Sigma Aldrich, Merck) solution using phenolphthalein (Sigma Aldrich, Merck) as an indicator. The neutralised alcohol was poured into the flask containing ghee. The contents were brought to boiling temperature in a boiling water bath (SUB Aqua 18 Plus; Grant Instruments). The solution, while hot, was titrated against $0.1 \mathrm{M}$ $\mathrm{NaOH}$ solution, shaking vigorously during titration. The end point of the titration was perceived when the addition of a single drop produced a slight but definite colour change which persisted for at least $15 \mathrm{~s}$. The FFA content was expressed as percentage of oleic acid as follows:

$$
\mathrm{FFA}=\left(\frac{2.82 \cdot V}{m}\right)
$$

where $V$ is the volume of $0.1 \mathrm{M} \mathrm{NaOH}(\mathrm{mL})$, and $m$ is the mass of the sample $(\mathrm{g})$.

\section{Statistical analysis}

The results were expressed as mean value \pm standard error of the mean. Significance was tested by employing one-way analysis of variance (ANOVA) and Fisher's least significant difference test. For computation of data, $\mathrm{SAS}^{\circledR}$ Studio v. 5.1 software (24) was used.

\section{RESULTS AND DISCUSSION}

\section{Sensory analysis of milk fortified with WPC-Fe complex}

The overall sensory scores were 95.95, 95.69, 92.23 and 91.16 for milk samples fortified with WPC-Fe complex containing 10, 15, 20 and $25 \mathrm{mg} / \mathrm{L}$ of iron, respectively, as compared to 96.58 obtained for control milk (data not shown). Statistically, the control and the milk samples fortified with up to 15 $\mathrm{mg} / \mathrm{L}$ of iron were significantly similar $(\mathrm{p}<0.05)$ in all sensory aspects, i.e. colour and appearance, odour, taste, mouthfeel and total scores. There were visible changes in colour, odor and taste of milk samples fortified with WPC-Fe complex containing above $15 \mathrm{mg} / \mathrm{L}$ of iron compared to the control milk. Hence, further study of milk fortified with WPC-Fe complex was restricted to up to $15 \mathrm{mg} / \mathrm{L}$ of iron.

\section{Heat stability of toned milk fortified with WPC-Fe complex}

The heat stability as heat coagulation time of control milk and milk fortified with iron and WPC-Fe complex was determined at their natural $\mathrm{pH}$ and after the $\mathrm{pH}$ value adjustment from 6.4 to 7.0 with 0.1-unit intervals using $\mathrm{NaH}_{2} \mathrm{PO}_{4}$ and $\mathrm{Na}_{2} \mathrm{H}$ $\mathrm{PO}_{4}$ (Fig. 1). It was evident from the result that heat coagulation time of toned milk and that of the fortified milk at their natural pH $\left(6.75,6.61\right.$ and 6.67 , respectively) and $(140 \pm 1){ }^{\circ} \mathrm{C}$ was: 25.70, 22.99 and 25.90 min, respectively. It was observed from the heat coagulation time vs pH curve that the maximum was on the acidic side of the natural $\mathrm{pH}$ of the milk, i.e. at 6.50 for all the samples. It was also observed that the heat coagulation time of milk fortified with iron salt ( $\gamma$ (iron) $=15 \mathrm{mg} / \mathrm{L}$ ) was lower than of milk fortified with WPC-Fe complex ( $\gamma$ (iron)=15 mg/L) and control milk at all the $\mathrm{pH}$ levels studied.
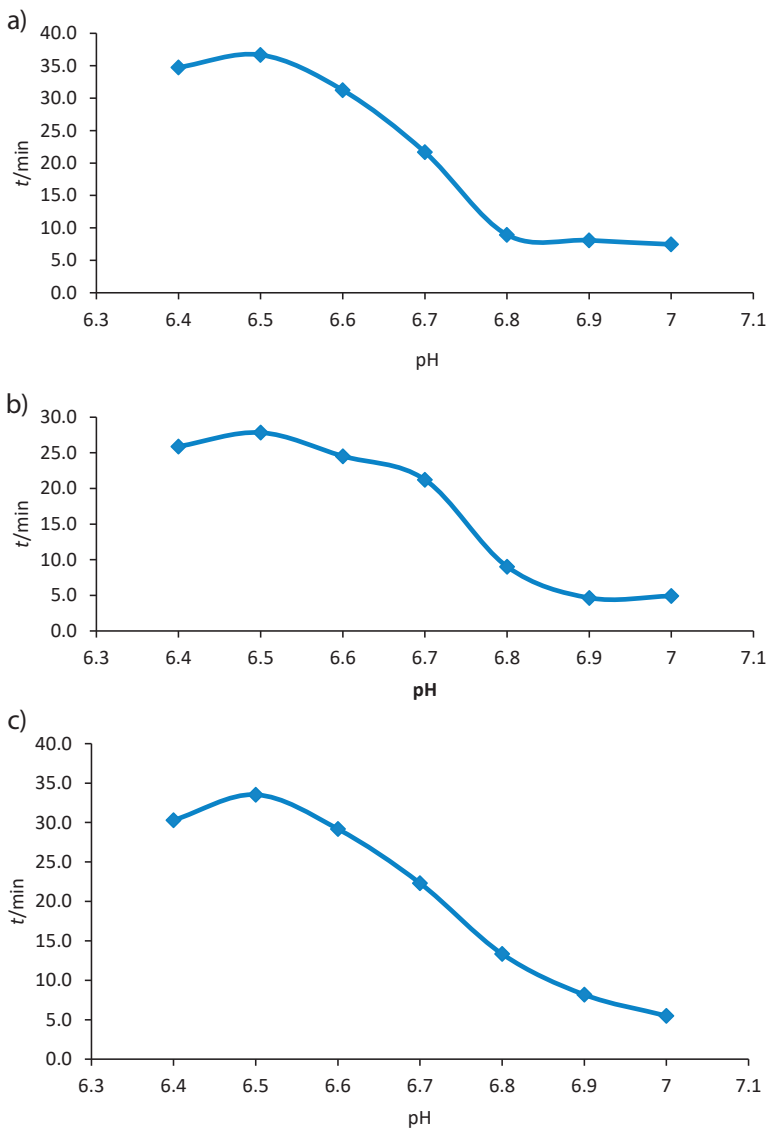

Fig. 1. Heat coagulation time at $140^{\circ} \mathrm{C}$ and different $\mathrm{pH}$ values: a) control, toned milk, and milk fortified with: b) iron salt, and c) WPC-Fe complex. $\gamma$ (iron) $=15 \mathrm{mg} / \mathrm{L}$ 
Thus, it could be inferred that the addition of iron (15 $\mathrm{mg} / \mathrm{L}$ ) in the free form to milk had a detrimental effect on its heat stability, while WPC-Fe complex (with the same concentration of bound iron) did not adversely affect the heat stability of the milk and could be processed at high temperatures without any visible aggregation or coagulation. This could be due to negligible change in initial $\mathrm{pH}$ (from 6.75 to 6.67) of milk after the addition of WPC-Fe complex. Gaucheron et al. (25) also reported that heat treatment of iron-supplemented skimmed milk containing $1.5 \mathrm{mM}$ iron at $95^{\circ} \mathrm{C}$ for $30 \mathrm{~min}$ caused no visible coagulation or aggregation. Sachdeva et al. (19) also found that the addition of iron(III) diphosphate and iron(III) gluconate hydrate at the concentration of $25 \mathrm{mg} / \mathrm{L}$ of iron to milk did not significantly alter its heat coagulation time compared to that of control milk. Shilpashree (26) also reported that fortification of milk with up to $30 \mathrm{mg} / \mathrm{L}$ of iron in the form of lyophilised WPC-Fe complex did not alter its heat coagulation time.

\section{Colour parameters of milk fortified with WPC-Fe complex}

Colour is an important criterion for acceptability of foods when fortifying with iron fortificants. Colour of control and milk fortified with iron as iron salt and as WPC-Fe complex was estimated after $24 \mathrm{~h}$ of storage at $4-5^{\circ} \mathrm{C}$. The differences in colour (sample minus control) for different colour profiles were also described in terms of $\Delta L, \Delta a$ and $\Delta b$ (Fig. 2). It was observed from the results that fortification of milk with iron salt significantly affected $(p<0.05)$ its colour profile compared to the control and milk with WPC-Fe complex. The $\Delta L, \Delta a$ and $\Delta b$ values of milk fortified with iron salt were $-1.74,-0.56$ and -2.3 , which indicated the change in colour of milk to dark, green and blue, respectively (Fig. 2). In the case of milk fortified with WPC-Fe complex, there was a negligible increase in the value of $\Delta L, \Delta a$ and $\Delta b$, i.e. $-0.82,-0.19$ and -0.13 . Raouche et al. (27) stated that the addition of $\mathrm{FeCl}_{3}$ into the milk alters the colour parameters of milk towards more red and yellowish, whereas of $\mathrm{FeCl}_{2}$ towards more red, yellowish and greyish. Raouche et al. (28) also reported that fortification of milk with iron or its individual segments such as casein and whey protein always leads to change in colour. There are some contradictory reports available which stated that there is no alteration in

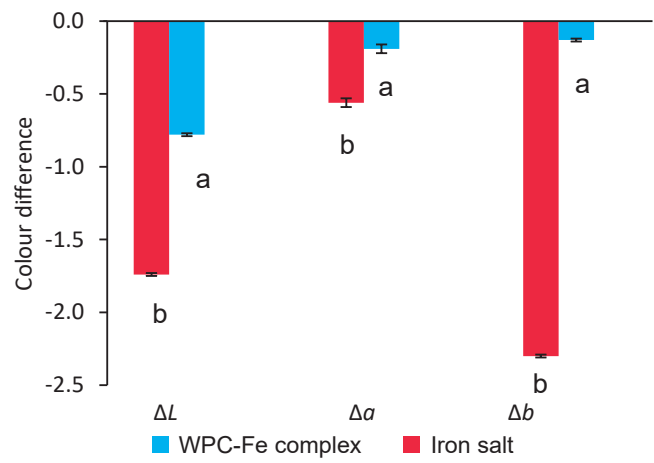

Fig. 2. Colour differences (sample minus control) for different colour parameters $(L, a$ and $b)$ of milk fortified with WPC-Fe complex compared to the milk fortified with iron salt. Samples designated with different letters were significantly $(p<0.05)$ different colour upon the addition of iron into milk. Douglas Jr et al. (29) stated that fortification of chocolate milk with iron(III)ammonium citrate and iron(III) diphosphate at the iron concentration of 10 $\mathrm{mg} / \mathrm{L}$ resulted in the darkening of chocolate milk which could be due to the difference in natural colour of milk and chocolate milk. Sachdeva et al. (19) also reported that milk fortified with iron(III) diphosphate, iron(II) gluconate hydrate and vitamin A at $25 \mathrm{mg} / \mathrm{L}$ of iron had no significant effect on the change of all colour parameters of milk. Shilpashree et al. (8) also found that milk fortified with lyophilised WPC-Fe complex at $30 \mathrm{mg} / \mathrm{L}$ of iron did not significantly alter the colour parameters of milk.

\section{Rennet coagulation time of the milk fortified} with WPC-Fe complex

Rennet coagulation time of control milk and milk fortified with iron salt and WPC-Fe complex ( $\gamma$ (iron) $=15 \mathrm{mg} / \mathrm{L}$ ) was determined (Fig. 3), and that of milk fortified with iron salt was significantly higher (1.93 min; $\mathrm{p}<0.05$ ) than that of the control and WPC-Fe complex fortified milk (1.57 and 1.55 min, respectively). The rennet coagulation time of milk fortified with WPC-Fe complex was comparable $(p<0.05)$ with that of the control milk. Gaucheron et al. (25) stated that an increase in the concentration of $\mathrm{FeCl}_{2}$ or $\mathrm{FeCl}_{3}$ in skimmed milk increased the rennet clotting time and aggregation time, and decreased the curd firmness. They also reported that the iron has no effect on the primary phase of rennet coagulation, suggesting that: (i) chymosin was probably not changed by iron ions, (ii) K-casein, having one or two phosphoseryl residues per molecule, was unchanged, and (iii) the preferential binding of iron to $a_{s 1}$-casein did not affect the enzymatic hydrolysis of k-casein.

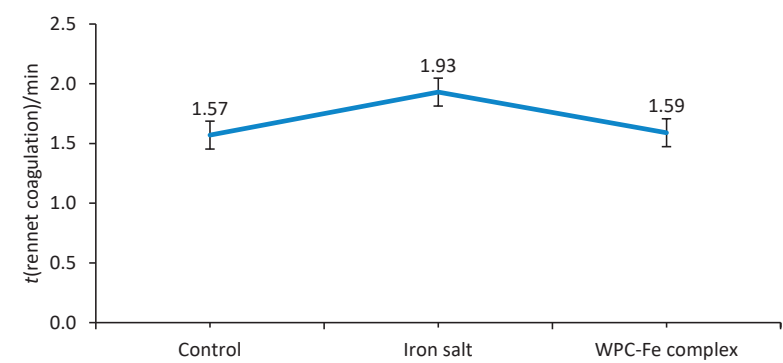

Fig. 3. Rennet coagulation time of control milk, and milk fortified with iron salt and WPC-Fe complex. $\gamma$ (iron) $=15 \mathrm{mg} / \mathrm{L}$

\section{Curd tension of the milk fortified with WPC-Fe complex}

The effect of WPC-Fe complex fortification on the curd tension of milk compared to that of the milk fortified with iron salt was determined and the results are presented in Fig. 4. Curd tension of milk fortified with iron salt was significantly lower $(p<0.05)$ than of the control milk and milk fortified with WPC-Fe complex.

It has previously been reported that the curd firmness of skimmed milk fortified with $\mathrm{FeCl}_{2}$ and $\mathrm{FeCl}_{3}$ decreased due to the alteration in the secondary (aggregation of paracasein micelles) and tertiary (gel formation) phases by modifications of molecular interactions between paracasein micelles in the presence of iron ions (25). This indicated that WPC-Fe complex 
reduced the reactivity of iron to alter milk system adversely when fortified with iron at the concentration of $15 \mathrm{mg} / \mathrm{L}$. Therefore, it could be inferred that cheese preparation from milk fortified with WPC-Fe complex would not interfere with rennet activity and hence with the firmness of cheese curd.

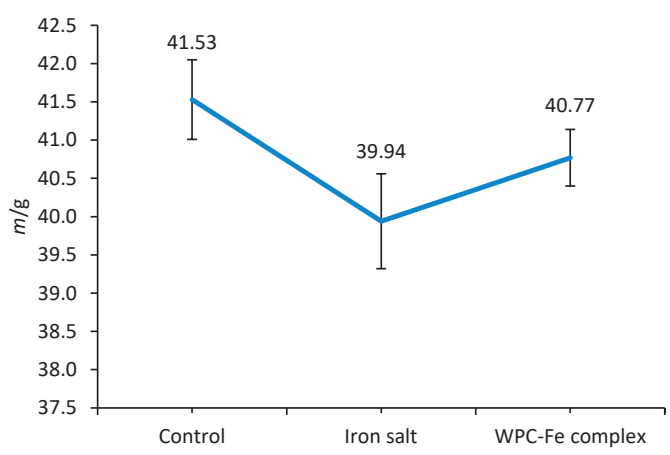

Fig. 4. Curd tension (expressed as mass in g) of control milk, and milk fortified with iron salt and WPC-Fe complex. $\gamma$ (iron) $=15 \mathrm{mg} / \mathrm{L}$

\section{Comparison of in vitro bioaccessibility of iron from milk fortified with WPC-Fe complex or iron salt}

The in vitro bioaccessibility of iron ( $\gamma($ iron $)=15 \mathrm{mg} / \mathrm{L}$ ) from milk fortified with WPC-Fe complex compared to that of the milk fortified with iron salt was examined using in vitro simulated gastrointestinal digestion system. The bioaccessibility of all the samples showed a significant difference $(p<0.05)$ from each other. Bioaccessibility of iron from milk fortified with WPC-Fe complex ((85.23 \pm 2.58$) \%)$ was significantly higher $(\mathrm{p}<0.05)$ than that of the milk fortified with iron salt ((72.15 \pm 3.52$) \%)$; data not shown. Among the most important reasons for lower bioavailability of iron from milk and milk products is the inhibitory effect of calcium and casein (30-32). Jackson and Lee (33) reported that human studies showed better bioavailability of iron in human milk due to the presence of lower amounts of casein, phosphate and calcium. They also reported that the definite causes for the difference in iron bioavailability between human and cow's milk have not been identified. Hurrell et al. (30) also reported the inhibitory effect of caseins on the absorption of iron in an in vitro analysis. However, they also described that the hydrolysis of proteins (casein and whey protein) and the presence of digested peptides positively correlated with the proportion of dialyzable iron. Kibangou et al. (34) also reported that casein inhibits iron absorption in humans, but protein hydrolysis lowers this effect. Turnlund et al. (35) studied in vivo and in vitro bioavailability of iron from cereal-based products and suggested that the absorption of iron from cereal-based diets was neither enhanced nor inhibited by the addition of milk. Saxena and Seshadri (36) revealed that the addition of milk to cereal products enhanced the in vitro bioavailability of iron significantly $(p<0.001)$.

Ranhotra et al. (37) studied the bioavailability of iron in pasteurised and homogenized cow's milk by the haemoglobin depletion-repletion technique using rats. They reported that milk or milk components did not adversely affect the bioavailability of added iron. Sharma (38) reported that iron fortification of milk enhanced iron bioavailability, which was higher when milk was fortified with lactose-iron complex than with iron salt. Ellis et al. (39) described a concept of absorption of iron in which keeping the solubility of iron at luminal surface was the first step for absorption. In fact, the iron in the form of WPC-Fe complex showed better bioaccessibility than that from iron salt and the importance of proteins during digestion of iron has been well described. Thus, it could be concluded that fortification of milk with iron in the form of WPC-Fe complex enhanced the bioaccessibility of added iron by keeping it soluble under the intestinal conditions.

\section{Storage study of the milk fortified with WPC-Fe complex}

Changes in sensory acceptability of milk fortified with WPC-Fe complex during storage compared to milk fortified with iron salt

The overall sensory scores obtained for control milk, milk fortified with WPC-Fe complex and iron salt at the beginning and on the 3rd, 5th and 7th days of storage are presented in Table 1. It is evident that milk fortified with iron salt received significantly lower $(p<0.05)$ scores for sensory aspects such as odour, taste, mouthfeel and total scores than control milk throughout the storage period. However, it showed significantly lower $(p<0.05)$ scores for colour on the 5 th day onwards than the control. Milk fortified with WPC-Fe complex showed non-significant differences in all sensory aspects (colour and appearance, odour, taste, mouthfeel and total scores) compared to the control throughout the sensory period (from day 0 to day 7). The results of sensory analysis after the 7th day of storage revealed that the milk fortified with WPC-Fe complex had good sensory acceptability for 7 days. However, the total sensory scores of milk fortified with WPC-Fe complex and control milk samples showed slight but statistically significant difference on the 7th day. From these results, it could be concluded that the sensory aspects of milk fortified with WPC-Fe complex were almost comparable to those of control milk up to 7 days. No data is available regarding the effect of storage on sensory acceptability of milk fortified with WPC-Fe complex. However, Douglas Jr et al. (29) studied the effect of different iron salts, including whey protein-iron(III) polyphosphate complex fortification, on colour and flavour of chocolate milk during storage for 14 days at $4{ }^{\circ} \mathrm{C}$. They reported that all samples including whey protein-Fe complex produced little or no off-flavour in chocolate milk initially or after 7 and 14 days of storage as compared to the control. Xia and Xu (40) fortified fluid whole milk with iron(II) sulfate liposomes $(\gamma$ (iron) $=15$ $\mathrm{mg} / \mathrm{L}$ ) and after one week of storage at $4{ }^{\circ} \mathrm{C}$ they observed that control and fortified milk were very stable without any signs of precipitation and coagulation, and fortified milk did not differ greatly from the control milk in colour and flavour. Ayyadurai et al. (41) also reported that no noticeable changes in flavour and acceptability scores were observed in milk fortified with iron(III) ammonium citrate and vitamin A after seven days of storage at $5^{\circ} \mathrm{C}$. Wang and King (42) reported that milk fortified with iron(III) ammonium citrate $(\gamma($ iron $)=15 \mathrm{mg} / \mathrm{L})$ was as stable as control 
Table 1. Sensory scores of milk fortified with WPC-Fe complex during storage in comparison to that of milk fortified with iron salt

\begin{tabular}{|c|c|c|c|c|}
\hline \multirow{2}{*}{ Characteristic } & \multirow{2}{*}{ Maximum score } & \multirow{2}{*}{ Control milk } & \multicolumn{2}{|c|}{ Milk fortified with } \\
\hline & & & Iron salt & WPC-Fe complex \\
\hline \multicolumn{5}{|c|}{ Sensory scores on day 0 of storage } \\
\hline Colour and appearance & 10 & $(9.60 \pm 0.08)^{a}$ & $(9.4 \pm 0.1)^{\mathrm{a}}$ & $(9.6 \pm 0.1)^{\mathrm{a}}$ \\
\hline Odour & 20 & $(19.5 \pm 0.1)^{a}$ & $(17.0 \pm 0.2)^{b}$ & $(19.1 \pm 0.1)^{a}$ \\
\hline Taste & 40 & $(38.8 \pm 0.2)^{\mathrm{a}}$ & $(35.7 \pm 0.2)^{\mathrm{b}}$ & $(38.5 \pm 0.1)^{\mathrm{a}}$ \\
\hline Mouthfeel & 30 & $(28.7 \pm 0.2)^{a}$ & $(28.1 \pm 0.1)^{b}$ & $(28.5 \pm 0.2)^{a}$ \\
\hline Total score & 100 & $(96.6 \pm 0.6)^{a}$ & $(90.2 \pm 0.4)^{\mathrm{b}}$ & $(95.7 \pm 0.5)^{\mathrm{a}}$ \\
\hline \multicolumn{5}{|c|}{ Sensory scores on the 3rd day of storage } \\
\hline Colour and appearance & 10 & $(9.5 \pm 0.1)^{\mathrm{a}}$ & $(9.2 \pm 0.1)^{\mathrm{a}}$ & $(9.4 \pm 0.1)^{\mathrm{a}}$ \\
\hline Odour & 20 & $(19.2 \pm 0.2)^{\mathrm{a}}$ & $(16.1 \pm 0.2)^{\mathrm{b}}$ & $(18.5 \pm 0.2)^{\mathrm{a}}$ \\
\hline Taste & 40 & $(38.4 \pm 0.3)^{a}$ & $(33.3 \pm 0.3)^{b}$ & $(38.0 \pm 0.4)^{\mathrm{a}}$ \\
\hline Mouthfeel & 30 & $(28.5 \pm 0.3)^{a}$ & $(27.1 \pm 0.3)^{b}$ & $(27.8 \pm 0.2)^{\mathrm{a}}$ \\
\hline Total score & 100 & $(95.7 \pm 0.4)^{\mathrm{a}}$ & $(85.7 \pm 0.6)^{b}$ & $(93.8 \pm 0.5)^{\mathrm{a}}$ \\
\hline \multicolumn{5}{|c|}{ Sensory scores on the 5 th day of storage } \\
\hline Colour and appearance & 10 & $(9.3 \pm 0.2)^{\mathrm{a}}$ & $(9.0 \pm 0.1)^{\mathrm{b}}$ & $(9.1 \pm 0.2)^{\mathrm{a}}$ \\
\hline Odour & 20 & $(18.5 \pm 0.1)^{\mathrm{a}}$ & $(15.5 \pm 0.3)^{b}$ & $(18.1 \pm 0.2)^{\mathrm{a}}$ \\
\hline Taste & 40 & $(38.0 \pm 0.2)^{\mathrm{a}}$ & $(29.2 \pm 0.5)^{\mathrm{b}}$ & $(37.0 \pm 0.3)^{a}$ \\
\hline Mouthfeel & 30 & $(27.1 \pm 0.3)^{a}$ & $(24.1 \pm 0.4)^{\mathrm{b}}$ & $(27.1 \pm 0.4)^{\mathrm{a}}$ \\
\hline Total score & 100 & $(93.0 \pm 0.4)^{\mathrm{a}}$ & $(77.9 \pm 0.6)^{b}$ & $(91.3 \pm 0.5)^{\mathrm{a}}$ \\
\hline \multicolumn{5}{|c|}{ Sensory scores on the 7th day of storage } \\
\hline Colour and appearance & 10 & $(9.01 \pm 0.1)^{\mathrm{a}}$ & $(7.04 \pm 0.1)^{b}$ & $(8.51 \pm 0.1)^{a}$ \\
\hline Odour & 20 & $(17.5 \pm 0.1)^{\mathrm{a}}$ & $(14.1 \pm 0.2)^{b}$ & $(16.8 \pm 0.2)^{\mathrm{a}}$ \\
\hline Taste & 40 & $(35.5 \pm 0.2)^{a}$ & $(27.3 \pm 0.2)^{\mathrm{b}}$ & $(35.3 \pm 0.2)^{\mathrm{a}}$ \\
\hline Mouthfeel & 30 & $(26.7 \pm 0.2)^{\mathrm{a}}$ & $(22.2 \pm 0.3)^{b}$ & $(25.4 \pm 0.4)^{\mathrm{a}}$ \\
\hline Total score & 100 & $(88.8 \pm 0.5)^{a}$ & $(70.7 \pm 0.4)^{c}$ & $(86.0 \pm 0.5)^{b}$ \\
\hline
\end{tabular}

Data are presented as mean value \pm standard error of the mean $(N=15)$. Mean values within the row with different lower-case letters in superscript are significantly different $(\mathrm{p}<0.05)$ from each other

without statistically significant differences in flavour after 7 days of storage. They also stated that the addition of iron(III) ammonium sulfate and iron(III) chloride resulted in detectable oxidized flavour after 7 days of storage and their flavour scores were significantly different from control. Demott (43) reported that iron(III) diphosphate and iron(III) phosphate (added at $\gamma$ (iron) $=5.2$ and $10.4 \mathrm{mg} / \mathrm{L}$, respectively) caused only minor off-flavours in whole and skimmed milk after 5 days storage at $4^{\circ} \mathrm{C}$.

Changes in viscosity of milk fortified with WPC-Fe complex during storage as compared to that of milk fortified with iron salt

Changes in viscosity of control and milk fortified with WPC-Fe complex compared to that of milk fortified with iron salt during storage are shown in Fig. 5 .

Control milk and milk fortified with WPC-Fe complex showed significant changes $(p<0.05)$ in viscosity on the 7th day of storage, whereas milk fortified with iron salt showed significant difference $(p<0.05)$ on the 5 th day of storage. Gaucheron et al. (44) reported that there was protein coagulation at $4.0 \mathrm{mM}$ of iron salt, which could possibly affect the viscosity of fortified milk. However, in the present work milk samples fortified with WPC-Fe complex showed viscosity comparable to control, which might be due to the unavailability of iron to affect milk proteins, especially caseins. Our results are in agreement with those of Shilpashree et al. (26), who also reported

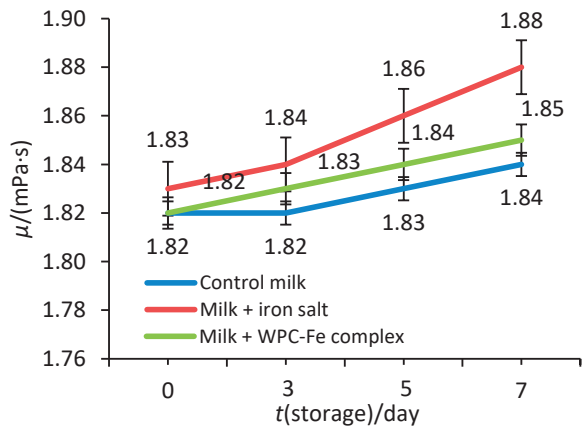

Fig. 5. Effect of storage at temperature between 4 and $7{ }^{\circ} \mathrm{C}$ on the viscosity of milk fortified with WPC-Fe complex compared to milk fortified with iron salt. $\gamma$ (iron) $=15 \mathrm{mg} / \mathrm{L}$

that lyophilised WPC-Fe complex ( $30 \mathrm{mg} / \mathrm{L}$ ) did not significantly affect the viscosity of milk up to the 5 th day of storage.

\section{TBA value}

The extent of lipid oxidation of fat extracted from milk fortified with iron salt and WPC-Fe complex ( $\gamma$ (iron) $=15 \mathrm{mg} / \mathrm{L}$ ) was evaluated during storage period (at the beginning and on the 3rd, 5th and 7th day) and compared with that of the control milk fat sample, and the results are shown in Fig. $6 a$.

There was a significant difference $(p<0.05)$ in the TBA value of fat extracted from control milk and that of the milk fortified with WPC-Fe complex even on the 3rd day of storage. It was evident (Fig. 6a) that TBA value of fat extracted from iron 
salt-fortified milk was slightly higher, i.e. 0.021, than that of fat extracted from control milk and WPC-Fe complex-fortified milk, i.e. 0.014 and 0.015 , respectively at the beginning of storage. The higher TBA value of iron salt-fortified milk fat may be due to the pro-oxidant effect of free iron, which acts on milk fat and induces lipid oxidation. Wang and King (42) reported that there was an increase in TBA value of milk when fortified with iron(II) sulfate. WPC makes iron unavailable to react with milk fat, thus inhibiting lipid oxidation to some extent.

\section{Peroxide value}

Peroxide value is the measure of hydroperoxides formed during autoxidation. Fig. $6 \mathrm{~b}$ gives the peroxide values of fat extracted from all the milk samples including control milk, and

a)

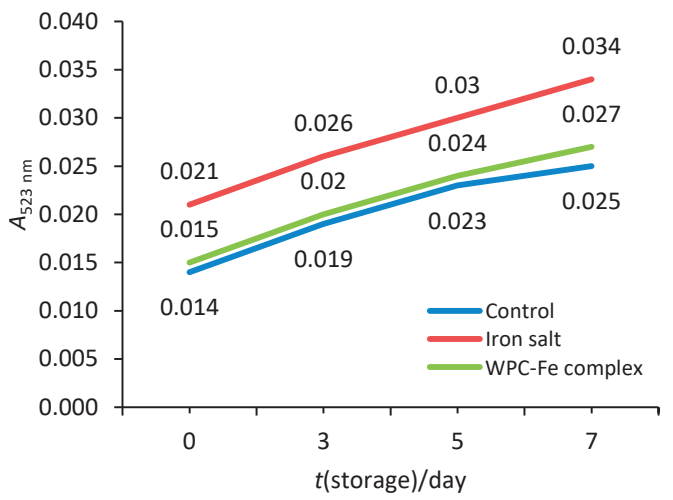

b)

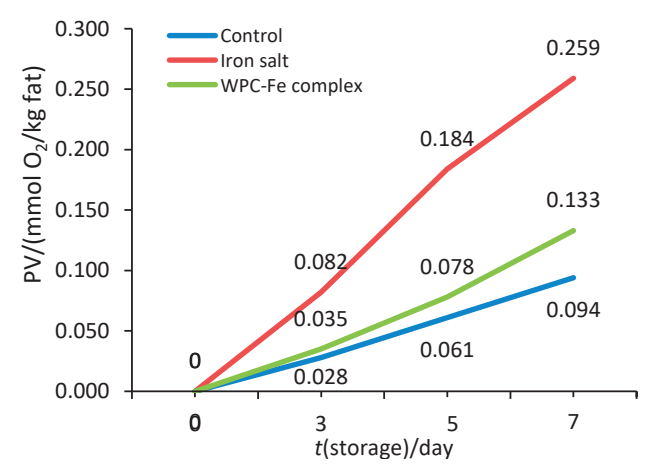

c)

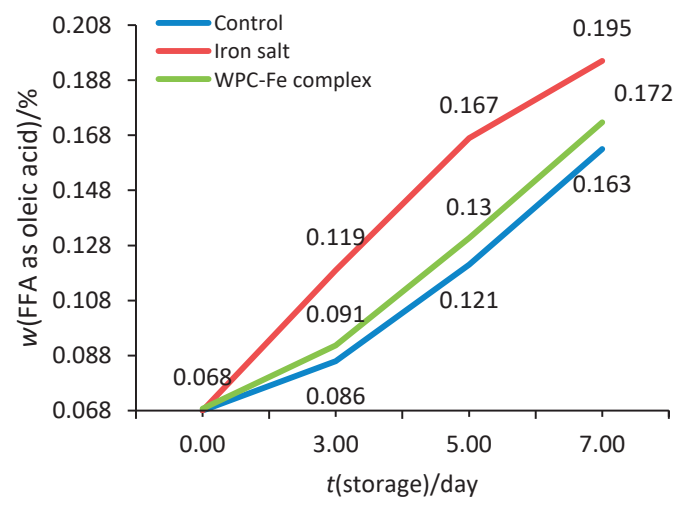

Fig. 6. Effect of storage (at temperature between 4 and $7{ }^{\circ} \mathrm{C}$ ) on: a) thiobarbituric acid (TBA) value expressed as absorbance at $\lambda=523 \mathrm{~nm}, \mathrm{~b}$ ) peroxide value (PV), and c) free fatty acid (FFA) content of ghee prepared from control and milk fortified with iron salt and WPC-Fe complex milk fortified with iron salt and WPC-Fe complex ( $\gamma$ (iron) $=15$ $\mathrm{mg} / \mathrm{L}$ ). It is evident from the results that there was non-significant difference $(p>0.05)$ in peroxide value of fat extracted from control milk and milk fortified with WPC-Fe complex. The peroxide value of fat extracted from WPC-Fe complex fortified milk was significantly lower $(p<0.05)$ than that of milk fortified with iron salt. The peroxide value of fat extracted from WPC-Fe complex fortified milk was comparable to the control milk fat up to the 5th day of storage. This demonstrated the protective effect provided by the complex on oxidation of fat by the iron salt. Hwang et al. (45) and Yi et al. (46) also reported the protective effect of WPC on oxidative stability of fish oil as indicated by decrease in the formation of primary and secondary lipid oxidation products. This may be due to the free sulfhydryl groups and aromatic amino acids in the whey proteins, which can act as free radical scavengers contributing to the antioxidant activity. Sachdeva et al. (19) have also reported that addition of iron(III) diphosphate and iron(II) gluconate at iron concentration of $25 \mathrm{mg} / \mathrm{L}$ in a complex with vitamin $A$ increased the peroxide value of milk fat significantly on the 3rd day of storage.

\section{Free fatty acid content}

Free fatty acids are formed by action of lipase on triglycerides and are indicators of hydrolytic rancidity. Fig. $6 \mathrm{c}$ shows the free fatty acid content of fat extracted from control milk, and milk fortified with iron salt and WPC-Fe complex ( $\gamma$ (iron) $=15 \mathrm{mg} / \mathrm{L}$ ). It is evident from the results that free fatty acid content of the fat extracted from milk fortified with iron salt was significantly $(p<0.05)$ higher than that from control milk and WPC-Fe-fortified milk up to the 5th day of storage. Free fatty acid content of control milk fat was lower (0.16\%) than that of fat from milk fortified with iron salt and WPC-Fe complex ( 0.20 and $0.17 \%$, respectively) on the 7 th day.

\section{Induction time}

The oxidative stability of the fat extracted from milk fortified with iron salt and WPC-Fe complex at the concentration of iron $15 \mathrm{mg} / \mathrm{L}$ after 7 days of storage at refrigerated temperature $\left(4-7^{\circ} \mathrm{C}\right)$ was evaluated using Rancimat. Fat extraction conditions for control milk sample were the same. Fig. 7 shows the induction period of different fat samples at 120 and $130^{\circ} \mathrm{C}$. It is evident that induction period $\left(17.08 \mathrm{~h}\right.$ at $120^{\circ} \mathrm{C}$ and $7.77 \mathrm{~h}$ at $130^{\circ} \mathrm{C}$ ) of fat extracted from iron salt-fortified milk was shorter than of that extracted from control milk $(26.52 \mathrm{~h}$ at $120^{\circ} \mathrm{C}$ and $12.32 \mathrm{~h}$ at $130^{\circ} \mathrm{C}$ ) and WPC-Fe complex-fortified milk ( $26.06 \mathrm{~h}$ at $120^{\circ} \mathrm{C}$ and $11.95 \mathrm{~h}$ at $130{ }^{\circ} \mathrm{C}$ ). This indicated that the addition of iron to milk as WPC-Fe complex reduced the catalytic activity of iron and maintained the oxidative stability of fat extract similar to control under accelerated oxidation conditions. Shilpashree (26) also reported that fortifying milk with lyophilised WPC-Fe complex $(\gamma$ (iron) $=30 \mathrm{mg} / \mathrm{L})$ did not significantly ( $p>0.05)$ affect the oxidative stability of fat. 


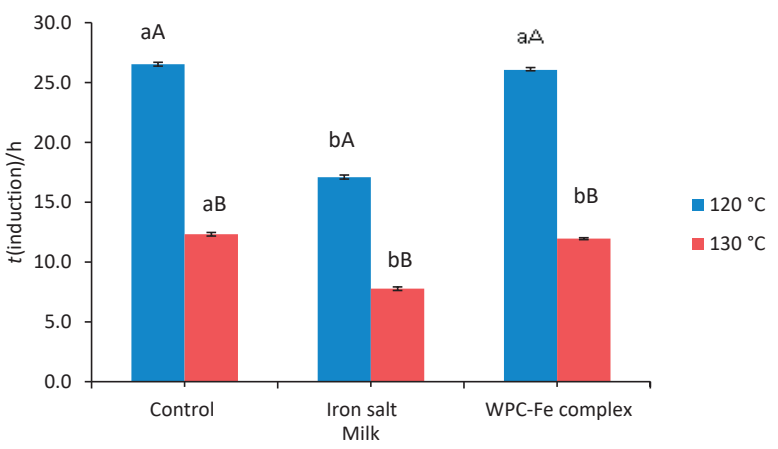

Fig. 7. Induction period of fat extracted from control milk and iron-fortified milk samples. Data are presented as mean value \pm standard error of the mean $(N=3)$. Samples designated with different lower-case letters were significantly different $(p<0.05)$. Samples designated with different upper-case letters were significantly different $(p<0.05)$ when compared at different temperatures

\section{CONCLUSIONS}

Milk fortified with $15 \mathrm{mg} / \mathrm{L}$ of iron in the form of whey protein concentrate-iron (WPC-Fe) complex showed high heat stability and good sensory acceptability compared to that of the milk fortified with $\mathrm{FeSO}_{4}$. In vitro bioaccessibility of iron from the milk fortified with WPC-Fe complex was higher than that from milk fortified with $\mathrm{FeSO}_{4}$. Thus, it could be inferred from the study that the milk fortified with spray-dried WPC-Fe complex could deliver iron to all age and social groups without causing any change in their food consumption patterns, with minimal effect on sensory acceptability, physicochemical characteristics and shelf life, thus alleviating the prevalent iron deficiency.

\section{CONFLICT OF INTEREST}

The authors declare that they have no conflict of interest.

\section{ACKNOWLEDGEMENTS}

The authors duly acknowledge the financial support from the Science and Engineering Research Board, Department of Science and Technology, Government of India under the Early Career Research Award Scheme project no. ECR/2016/000835.

\section{REFERENCES}

1. Lopez A, Cacoub P, Macdougall IC, Peyrin-Biroulet L. Iron deficiency anaemia. Lancet. 2016;387(10021):907-16. https://doi.org/10.1016/S0140-6736(15)60865-0

2. Nestel P, Bouis HE, Meenakshi JV, Pfeiffer W. Biofortification of staple food crops. J Nutr. 2006;136:1064-7.

https://doi.org/10.1093/jn/136.4.1064

3. Hurrell RF. Preventing iron deficiency through food fortification. Nutr Rev. 1997;55(6):210-22.

https://doi.org/10.1111/j.1753-4887.1997.tb01608.x

4. Gaucheron F. Iron fortification in dairy industry. Trends Food Sci Technol. 2001;11(11):403-9.

https://doi.org/10.1016/S0924-2244(01)00032-2

5. Guzun-Cojocaru T, Cayot P, Loupiac C, Cases E. Effect of iron chelates on oil-water interface, stabilized by milk proteins:
The role of phosphate groups and $\mathrm{pH}$. Prediction of iron transfer from aqueous phase toward fat globule surface by changes of interfacial properties. Food Hydrocolloid. 2010; 24(4):364-73.

https://doi.org/10.1016/j.foodhyd.2009.11.002

6. Yadav JSS, Yan S, Pilli S, Kumar L, Tyagi RD, Surampalli RY. Cheese whey: a potential resource to transform into bioprotein, functional/nutritional proteins and bioactive peptides. Biotechnol Adv. 2015;33(6):756-74.

https://doi.org/10.1016/j.biotechadv.2015.07.002

7. Guzun-Cojocaru T, Koev C, Yordanov M, Karbowiak T, Cases E, Cayot P. Oxidative stability of oil-in-water emulsions containing iron chelates: Transfer of iron from chelates to milk proteins at interface. Food Chem. 2011;125(2):326-33. https://doi.org/10.1016/j.foodchem.2010.08.004

8. Shilpashree BG, Arora S, Sharma V. Preparation of iron/zinc bound whey protein concentrate complexes and their stability. LWT - Food Sci Technol. 2016;66:514-22.

https://doi.org/10.1016/j.lwt.2015.11.005

9. Wang ZL, Finlay WH, Peppler MS, Sweeney LG. Powder formation by atmospheric spray-freeze-drying. Powder Technol. 2006;170(1):45-52.

https://doi.org/10.1016/j.powtec.2006.08.019

10. Alhalaweh A, Velaga SP. Formation of cocrystals from stoichiometric solutions of incongruently saturating systems by spray drying. Cryst Growth Des. 2010;10(8):3302-5. https://doi.org/10.1021/cg100451q

11. Sosnik A, Seremeta KP. Advantages and challenges of the spray-drying technology for the production of pure drug particles and drug-loaded polymeric carriers. Adv Colloid Interface Sci. 2015;223:40-54.

https://doi.org/10.1016/j.cis.2015.05.003

12. Patel BB, Patel JK, Chakraborty S. Review of patents and application of spray drying in pharmaceutical, food and flavor industry. Recent Pat Drug Deliv Formul. 2014;8(1):63-78. https://doi.org/10.2174/1872211308666140211122012

13. Stipanuk MH, Caudill MA, editors. Biochemical, physiological, and molecular aspects of human nutrition - E-book. St. Louis, MO, USA: Elsevier Health Science; 2013.

14. Design-Expert, v. 10.0.8, State-Ease, Inc, Minneapolis, MN, USA; 2018. Available from: https://www.statease.com/software/downloads-updates.html.

15. IS 7768-1975. Methods for sensory evaluation of milk. New Delhi, India: Bureau of Indian Standards (BIS); 1975.

16. Jairam BT, Vijayalakshmi BT, Balakrishnan KGS, Nair PG. A study on heat stability of cow's milk using an indigenous device. Indian J Dairy Sci. 1976;29(3):222-6.

17. Berridge NJ. Some observations on the determination of the activity of rennet. Analyst. 1952;77(911):57-62.

https://doi.org/10.1039/an952770057b

18. Chandrasekhara MR, Bhagawan RK, Swaminathan M, Subrahmanyan V. The use of mammalian milk and processed milk foods in the feeding of infants. Indian J Child Health.1957;6:701-10. 
19. Sachdeva B, Kaushik R, Arora S, Indumathi KP. Impact of fortification with iron salts and vitamin A on the physicochemical properties of laboratory-pasteurised toned milk and bioaccessibility of the added nutrients. Int J Dairy Technol. 2015;68(2):253-60.

https://doi.org/10.1111/1471-0307.12185

20. De S, editor. Outlines of dairy technology. New Delhi, India: Oxford University Press; 1980.

21. Sidwell CG, Salwin H, Benca M, Mitchell Jr. JH. The use of thiobarbituric acid as a measure of fat oxidation. J Am Oil Chem Soc.1954;31(12):603-6. https://doi.org/10.1007/BF02545589

22. Pawar N, Purohit A, Gandhi K, Arora S, Singh RRB. Effect of operational parameters on determination of oxidative stability measured by Rancimat method. Int J Food Prop. 2014; 17(9):2082-8.

https://doi.org/10.1080/10942912.2012.680220

23. IS 3508-1966. Methods for sampling and test for ghee (butterfat). New Delhi, India: Bureau of Indian Standards; 1966.

24. SAS ${ }^{\circledR}$ Studio 5.1: User's guide, SAS Institute Inc, Cary, NC, USA; 2018. Available from: http://documentation.sas.com/ api/docsets/webeditorug/5.1/content/webeditorug.pdf?locale=en.

25. Gaucheron F, Le Graet Y, Raulot K, Piot M. Physicochemical characterization of iron-supplemented skim milk. Int Dairy J. 1997;7(2-3):141-8. https://doi.org/10.1016/S0958-6946(96)00054-4

26. Shilpashree BG. Development and evaluation of milk protein-mineral complexes [PhDThesis]. Karnal, India: National Dairy Research Institute; 2015.

27. Raouche S, Dobenesque M, Bot A, Lagaude A, Marchesseau S. Casein micelles as a vehicle for iron fortification of foods. Eur Food Res Technol. 2009;229(6):929-35.

https://doi.org/10.1007/s00217-009-1130-0

28. Raouche S, Naille S, Dobenesque $M$, Bot A, Jumas JC, Cuq $J \mathrm{~L}$, Marchesseau S. Iron fortification of skim milk: minerals and ${ }^{57} \mathrm{Fe}$ Mössbauer study. Int Dairy J. 2009;19(1):56-63.

https://doi.org/10.1016/j.idairyj.2008.07.003

29. Douglas Jr FW, Rainey NH, Wong NP, Edmondson LF, LaCroix DE. Color, flavor, and iron bioavailability in iron-fortified chocolate milk. J Dairy Sci. 1981;64(9):1785-93.

https://doi.org/10.3168/jds.S0022-0302(81)82767-1

30. Hurrell RF, Lynch SR, Trinidad TP, Dassenko SA, Cook JD. Iron absorption in humans as influenced by bovine milk proteins. Am J Clin Nutr. 1989;49(3):546-52.

https://doi.org/10.1093/ajcn/49.3.546

31. Lynch SR. The effect of calcium on iron absorption. Nutr Res Rev. 2000;13(2):141-58.

https://doi.org/10.1079/095442200108729043

32. Bosscher D, Lu Z, Van Cauwenbergh R, Van Caillie-Bertrand $\mathrm{M}$, Robberecht $\mathrm{H}$, Deelstra $\mathrm{H}$. A method for in vitro determination of calcium, iron and zinc availability from first-age infant formula and human milk. Int J Food Sci Nutr. 2001;52(2):173-82.

https://doi.org/10.1080/09637480020027000
33. Jackson LS, Lee K. The effect of dairy products on iron availability. Crit Rev Food Sci Nutr. 1992;31(4):259-70.

https://doi.org/10.1080/10408399209527573

34. Kibangou IB, Bouhallab S, Henry G, Bureau F, Allouche S, Blais $A$, et al. Milk proteins and iron absorption: Contrasting effects of different casein phosphopeptides. Pediatr Res. 2005;58(4):731-4.

https://doi.org/10.1203/01.PDR.0000180555.27710.46

35. Turnlund JR, Smith RG, Kretsch MJ, Keyes WR, Shah AG. Milk's effect on the bioavailability of iron from cereal-based diets in young women by use of in vitro and in vivo methods. Am J Clin Nutr. 1990;52(2):373-8. https://doi.org/10.1093/ajcn/52.2.373

36. Saxena A, Seshadri S. The effect of whole milk, milk protein and some constituent amino acids on the in vitro availability of iron from cereal meals. Nutr Res. 1988;8(7):717-24. https://doi.org/10.1016/S0271-5317(88)80152-0

37. Ranhotra GS, Gelroth JA, Torrence FA, Bock MA, Winterringer GL. Bioavailability of iron in iron-fortified fluid milk. J Food Sci. 1981;46(5):1342-4.

https://doi.org/10.1111/j.1365-2621.1981.tb04169.x

38. Sharma A. Preparation and evaluation of physicochemical and techno-functional attributes of lactose-mineral complexes [MSc Thesis]. Karnal, India: National Dairy Research Institute; 2014.

39. Ellis A, Mittal V, Sugiarto M. Innovation in iron fortification: Is the future in iron-binding milk proteins? In: Ghosh D, Das S, Bagchi D, Smarta RB, editors. Innovation in healthy and functional foods. New York, NY, USA: CRC Press; 2013. pp. 249-67.

https://doi.org/10.1201/b13022

40. Xia S, Xu S. Ferrous sulfate liposomes: preparation, stability and application in fluid milk. Food Res Int. 2005;38(3):289-96. https://doi.org/10.1016/j.foodres.2004.04.010

41. Ayyadurai K, Pugazhenthi TR, Vijayalakshmi R, Narasimhan $\mathrm{R}$, Khan MMH. Studies on fortification of skim milk with iron and vitamin A. Indian J Dairy Biosci. 1999;10:59-63.

42. Wang CF, King RL. Chemical and sensory evaluation of iron-fortified milk. J Food Sci. 1973;38(6):938-40.

https://doi.org/10.1111/j.1365-2621.1973.tb02118.x

43. Demott BJ. Effects on flavor of fortifying milk with iron and absorption of iron from intestinal tract of rats. J Dairy Sci. 1971;54(11):1609-14.

https://doi.org/10.3168/jds.S0022-0302(71)86079-4

44. Gaucheron F, Legraet Y, Boyaval E, Piot M. Binding of cations to casein molecules: Importance of physico-chemical conditions. Milchwissenschaft. 1997;52(6):322-7.

45. Hwang JY, Ha HK, Lee MR, Kim JW, Kim HJ, Lee WJ. Physicochemical property and oxidative stability of whey protein concentrate multiple nanoemulsion containing fish oil. J Food Sci. 2017;82(2):437-44. https://doi.org/10.1111/1750-3841.13591

46. Yi T, Li SM, Fan JY, Fan LL, Zhang ZF, Luo P, et al. Comparative analysis of EPA and DHA in fish oil nutritional capsules by GC-MS. Lipids Health Dis. 2014;13:Article no. 190. https://doi.org/10.1186/1476-511X-13-190 